\title{
Results and Prospects in Apple Breeding
}

\author{
Sedov E. N. \\ SSI All Russian Research Institute of Fruit Crop Breeding, Orel, Russia \\ *Corresponding Author: nauka@vniispk.ru
}

Copyright @ 2013 Horizon Research Publishing All rights reserved.

\begin{abstract}
The results of many-year investigation of some features of apple ontogenesis in connection with breeding and propagation of new cultivars are briefly given. On the ground of 60-year work on apple breeding the author of this paper have attempted to retrace the changes in breeding goals and methods and record the most urgent trends in breeding at present and the nearest future. The contemporary and rapidly increasing demands for new cultivars are noted. The topical character of the development of the cultivars with improved biochemical fruit composition, high resistance and immunity to scab and powdery mildew and also varieties with complex resistance to the cardinal diseases and pests is shown. On the ground of the wide experimental material the author shows the prospects of the development of triploid cultivars which are notable for more regular fruit-bearing, high fruit marketability and higher autogamy. The development of triploid and scab immune apple cultivars is of particular interest. The urgency of columnar apple creation for super intensive orchards is noted. The experience in the hybrid pool establishing for the purpose of selecting highly winter hardy intercalary stocks of different vigour is presented. The prospects of the development of true-rooted apple trees and also autogamous cultivars with the use of apetalous plants are noted.
\end{abstract}

Keywords Apple, Cultivars, Ontogenesis, Breeding Goals And Methods, Biochemical Composition, Immunity To Scab, Triploid Cultivars, Autogamy

\section{Introduction}

It is advisable that an originator should know and consider ontogenesis features of a crop.

For many years we have studied the features of the individual apple development, which allowed revealing a number of regularities in the apple ontogenesis (Sedov, 1966, 1968).

1. It has been revealed that age diversity in the trunk height is observed even in apple seedlings of $24 . . .34$-years old, which is expressed in a presence of juvenile characters in one-year-old seedlings (heavy branching, small sharp-serrated leaves and their poor pubescence) when cuttings from a lower part of a crown, coppice shoots and from different root zones of annual seedlings were used as a grafting material. With advancing, these differences are gradually smoothed out in vegetatively propagated plants and by a moment of fruit-bearing the plants of different variants practically do not differ.

2. It has been determined that plants grown from cuttings of coppice shoot and also plants obtained from seedling roots usually start fruit-bearing 1-3 years later than plants grown from cuttings of the upper part of a crown of the same seedlings.

3. Apple plants of the rooting origin (from adventitious buds of seedlings) in their readiness for fruit-bearing are not equal to those plants, which are grown from seeds. The rooting system of apple seedlings though slower than the above-ground part of the plants, passes certain qualitative changes connected with the individual development. We have not found any differences in a degree of readiness for fruiting in apple plants of root origin obtained from root zones of seedlings different according to the remoteness from the root neck $(0 \ldots 20 \mathrm{sm} ; 20 \ldots 40 \mathrm{sm} ; \ldots$ $140 \ldots 160 \mathrm{sm})$.

4. As a rule, by a moment of fruit-bearing the plants obtained from the adventitious buds on the roots of apple seedlings have all traits which are characteristic for the cultivar. When grafting plants with juvenile characters on a rootstock, the cultivar features are reserved and that testifies the lack of changes of the inheritance order in such cases.

5. Late entry of apple seedlings into fruit-bearing is connected with the prolonged juvenile period. For quicker passing of the juvenile period and early entry into fruit-bearing it is necessary for apple seedlings to develop a significant vegetative mass. Only reaching a certain vegetative mass the seedlings are able to start fruiting.

6. The plants obtained from adventitious buds of additional roots of cultivar plants are ontogenetically mature organisms though they carry a number of features of "wildness", which are characteristic of juvenile seedlings. 
7. The long-term study of the relationship between morphological and biological features of young 1-4 year-old apple seedlings, on the one hand, and production qualities of grown-up plants, on the other hand, allows concluding the following:

- a close positive relationship is noted between the vigorousness and precocity of seedlings;

- a positive relationship has been revealed between the intensiveness of the autumn color of leaves and fruit color in grown-up apple seedlings; apple seedlings with fruit of summer ripening usually get an intensive color of leaves earlier;

- much more apple forms with better taste of fruit are selected among those seedlings, which at the age of one year have large leaves with short petioles;

- twice as many selected forms are picked out among apple seedlings, which at the age of 3-4 years have higher general selection appraisal, than among seedlings with low selection appraisal (Table 1).

Table 1. Relationship between the general selection appraisal of 3-4 year-old seedlings at the breeding nursery and selected seedling output in the orchard

\begin{tabular}{|c|c|c|c|c|c|}
\hline \multirow{2}{*}{$\begin{array}{c}\text { General selection } \\
\text { appraisal of 3-4 } \\
\text { year-old seedlings at } \\
\text { the breeding nursery }\end{array}$} & Seedlings & \multicolumn{2}{|c|}{$\begin{array}{c}\text { Output of selected } \\
\text { seedlings in the } \\
\text { orchard }\end{array}$} & \multicolumn{2}{|c|}{$\begin{array}{c}\text { Difference } \\
\text { sccording to } \\
\text { seedling groups }\end{array}$} \\
\cline { 4 - 7 } & & quantity & $\mathrm{P}(\%)$ & $\mathrm{P}_{1}-\mathrm{P}_{\mathrm{i}}$ & $\mathrm{P}_{2} \mathrm{P}_{\mathrm{i}}$ \\
\hline High (point 4 and 5) & 957 & 18 & 1,88 & - & \\
\hline Medium (point 3) & 5037 & 60 & 1,19 & $+0,69$ & - \\
\hline Low (point 1and 2) & 1328 & 11 & 0,83 & $+1,05^{*}$ & $+0,36$ \\
\hline
\end{tabular}

The revealed relationships of morphological and biological features of young seedlings with production-valuable qualities of grown-up seedlings are used in breeding practice.

However, it should be noted that the culling of 1-4 year-old apple seedlings according to the morphological traits must be done very carefully before their planting to the orchard. It is necessary to use a complex of traits associated between each other. First of all, the seedling origin, winter hardiness and disease resistance should be taken into account. The principal method of apple seedling rejection according to the winter hardiness at early stages of seedling development is freezing in chambers with artificial climate. Seedling rejection after infection on the artificial backgrounds or with the use of Marker Assisted Selection is the principal method of culling according to the disease resistance.

Plants with typical cultivar traits usually grow when using stem or root cuttings from one-year seedlings and also suckers from cultivar trees as grafting material. These plants do not differ from control plants (grown from common tree cuttings) in their entry into fruit-bearing, yield and marketable qualities of fruit.

Probably, plant obtaining from adventitious buds of cultivar trees (trees of root origin and partly form suckers) leads to the identification of those spontaneous clonal variations, which occurred in initial plants earlier. For this reason, the use of suckers as cuttings for budding or grafting should be avoided in the nursery.

At the same time, cuttings from young not yet fruiting trees in the orchard or from 1-2 year-old seedlings at the nursery and mother plantation of a meadow type may be used if the exclusion of confusion in belonging of the initial plants to a certain pomological cultivar is guaranteed.

Knowledge of the features of the individual development of fruit seedlings gives additional possibilities of rejecting unpromising selection seedlings at early stages of their development.

The identified biological features in ontogenetically mature cultivar plants allow more sufficient growing of planting material at the nurseries.

The demands to fruit cultivars have significantly changed for the last 60 years, especially in connection with the horticulture intensification. New sections have appeared in breeding: the first home scab immune apple cultivars have been developed; a new series of triploid cultivars from different-chromosomal crossings have been obtained in Russia and in the world; a number of columnar apple cultivars have been developed; searching investigations on other sections are being carried out.

An interdisciplinary group of scientific workers is involved in apple breeding work at the All Russian Research Institute of Fruit Crop Breeding (VNIISPK, Orel, Russia). The cultivar assessment for resistance to unfavorable winter conditions is fulfilled by breeders in collaboration with the laboratory of winter-hardiness; breeding for the improvement of chemical composition of fruit and their suitability for processing is executed jointly with the laboratory of biochemical and technological fruit assessment; breeding on a polyploidy level - with the laboratory of cytoembryology; the independent estimation of economic and biological features of new cultivars - with the laboratory of variety investigation; and breeding for scab resistance was previously carried out at the laboratory for disease resistance. The research workers of apple breeding laboratory and all laboratories mentioned above are co-authors of the cultivars. As an author of this article, I would welcome an opportunity to express my appreciation for their work.

Locality and methods of investigations. In 1953-1955 the hybridization was carried out at the I.V. Michurin's Research Institute of Horticulture (Michurinsk, Russia). Then hybrid seeds and one- and two-year hybrid seedlings were taken to Orel and since 1956 till nowadays the breeding work has been carried out at the All Russian Research Institute of Fruit Crop Breeding (VNIISPK, Orel, Russia, former Orel Zonal Fruit-Berry Experimental Station).

The conventional methods were used in the research work 
(Programme and Methods of Breeding of Fruit, Berry and Nut Crops. - Michurinsk, 1980 and Orel: VNIISPK, 1995).

The biochemical composition of fruit was studied in the laboratory of biochemical assessment of the cultivars bred at the institute. The content of soluble dry substances was determined by refractometric method; sugars - by Bertran method; titrated acids - by extract titrating with sodium hydroxide, $0,1 \mathrm{~N}$; ascorbic acid - by extract titrating with Tilmans paint; phenolics - by colorimetric method (L. I. Vigorov's modification) and pectins were determined by carbazole method (Programme and methods of breeding of fruit, berry and nut crops, 1980, 1995; Methods of biochemical investigation of plants, 1987).

\section{Results. Up-to-date Demands to Apple Cultivars}

At present, high demands are made for new apple cultivars. First of all, cultivars should be absolutely resistant at the area of cultivation, scab immune $\left(V_{f}\right)$ or highly resistant to scab and powdery mildew $\left(P l_{1}\right.$ and $\left.P l_{2}\right)$, they should have high precocity and productivity (up to $70 \mathrm{t} / \mathrm{ha}$ ) and regular fruit-bearing. Consumers make high demands of fruit quality. Fruit should be attractive and with bright color (purely red, yellow or green). Roundish or spherical shape of fruit is desirable. Skin should be thin but firm, without rustiness and wax bloom. Fruit taste should be with a harmonious combination of sugar and acid and with sugar-acid index 15-25, fruit flesh - juicy, crispy and small-grainy.

Fruit store ability of winter cultivars must be not less than 7 - 8 months. It is desirable that ascorbic acid content is 30 $\mathrm{mg} / 100 \mathrm{~g}$. An output of high-quality fruit should be not less than $80-90 \%$ (Kichina, 2011).

Obviously, it is impossible to develop an ideal cultivar, since the conception of an ideal cultivar is changed quickly, but we should aim at it.

\section{Development of Cultivars with Improved Biochemical Fruit Composition}

Apples are valuable in the dietary; they also favour better assimilation of other nutrient substances, particularly, proteins and mineral salts. Apple is a valuable source of sugars, organic acids, pectin, volatile oils, ascorbic acid (vitamin C) and biologically active phenolics (vitamin P).

Focused apple breeding for higher content of ascorbic acid in fruit has been carried out at the All Russian Research Institute of Fruit Crop Breeding since 1970 in collaboration with the laboratory of biochemical and technological fruit assessment (chief: Z.A.Sedova, M.A. Makarkina).

It is confirmed that the content of soluble dry substances and sugars in fruit is polygenically inherited.

The analysis of the hybrid progeny have showed that according to the content of titrated acids in fruit a positive domination and positive super domination (positive heterosis) are observed in a number of families. Our experimental data (Sedov, Sedova, 1985) confirm A. Brown's and D. Harvey's (1971) view that "acidity" trait is under monogenic and polygenic control simultaneously.

Homozygous sweet apple cultivars usually have insipid or insipid-sweet taste. Such seedlings are usually rejected. In connection with this, the most promising crossings are the crossings between homozygous sour cultivars and homozygous sweet ones (MaMa x mama). In such crossings all seedlings will be heterozygous ones and they will not be rejected because of insipid or insipid-sweet taste (Brown, Harvey, 1971). It is shown that according to the content of titrated acids sweet apple "Nesravnennoye" is homozygous in recessive (mama) (Sedov, Sedova, 1982).

Table 2. Apple cultivars having high content of phenolics in fruit (on an average for many years)

\begin{tabular}{|c|c|c|c|c|}
\hline \multirow{2}{*}{ № } & \multirow[b]{2}{*}{ Cultivar } & \multicolumn{2}{|c|}{ Sum of phenolics, $\mathrm{mg} / 100 \mathrm{~g}$} & \multirow[b]{2}{*}{ Coefficient of variation $\mathrm{V}, \%$} \\
\hline & & $\overline{\mathrm{x}} \pm \mathrm{m}$ & $\begin{array}{l}\text { Limits of diversity } \\
\text { min-max }\end{array}$ & \\
\hline & Chistotel & $460 \pm 47$ & $199-736$ & 33,7 \\
\hline & Afrodita & $464 \pm 82$ & $325-684$ & 35,3 \\
\hline & Pamyt Semakinu & $474 \pm 63$ & $281-631$ & 29,9 \\
\hline & Bolotovskoye & $477 \pm 34$ & $408-666$ & 18,9 \\
\hline & Vita & $486 \pm 59$ & $312-672$ & 27,2 \\
\hline & Rozhdestvenskoye & $495 \pm 110$ & $308-687$ & 38,4 \\
\hline & Avgusta & $502 \pm 90$ & $319-735$ & 35,9 \\
\hline & Orlovski pioneer & $514 \pm 46$ & $307-655$ & 26,6 \\
\hline & Candil orlovski & $558 \pm 42$ & $372-670$ & 18,5 \\
\hline \multicolumn{5}{|c|}{ Control wide-spread cultivars } \\
\hline & Severny sinap & $137 \pm 26$ & $92-147$ & 56,0 \\
\hline & Osenneye polosatoye & $248 \pm 42$ & $119-517$ & 50,6 \\
\hline & Papirovka & $259 \pm 20$ & $174-358$ & 23,2 \\
\hline & Antonovka obyknovennaya & $340 \pm 28$ & $141-511$ & 32,4 \\
\hline & Melba & $389 \pm 41$ & $210-603$ & 33,4 \\
\hline
\end{tabular}


As a result of large-scale apple breeding for higher content of ascorbic acid in fruit 18600 seedlings have been selected and grown. Those seedlings have been obtained from target crossings. A number of dependencies of ascorbic acid accumulation from some morphological and biochemical traits have been determined: low negative correlation - with fruit weight, weak $\left(\mathrm{r}=+0,17^{* *}, \mathrm{r}=+0,03\right)$ and fair $(\mathrm{r}=$ $+0,41 * * *)$ correlation - with the content of soluble dry substances and also weak correlation between ascorbic acid content and sum of sugars in fruit $\left(\mathrm{r}=+0,16^{* *},+0,28^{* * *}\right.$ and $\left.+0,16^{*}\right)$. Weak $(+0,23 * * *)$ to fair $(+0,43 * * *)$ correlation degrees have been determined between ascorbic acid content and titrated acids and also between ascorbic acid content and phenolics. Weak correlation and its lack between ascorbic acid content in fruit and degree of leaf and fruit infection with scab gives a ground to propose that the breeding of cultivars combining high vitamin content and scab resistance is possible.

In apple breeding for higher ascorbic acid content in fruit a new stage is connected with target multiple crossings when the best seedlings from simple crossings are used between each other or with cultivars having high content of vitamins.

New apple cultivars having higher ascorbic acid content in fruit (over $15 \mathrm{mg} / 100 \mathrm{~g}$ ) have been developed and included in the State Register: "Kulikovskoye", "Maslovskoye", "Veteran", etc. (Sedov, Makarkina, Levgerova, 2007). Unfortunately, breeders of the Middle regions of Russia have not managed to develop apple cultivars with ascorbic acid content not less than 25-30 $\mathrm{mg} / 100 \mathrm{~g}$ that is required in the Complex Breeding Programme for 2001-2020. - Orel, 2001.

Significantly great success has been achieved in the development of apple cultivars with high content of polyphenolics in fruit. Many new apple cultivars developed at the All Russian Research Institute of Fruit Crop Breeding are characterized by high content of polyphenolics (over
450-639 mg/100g): "Afrodita", "Pamyat Semakinu", "Yablochny Spas", "Avgusta" and "Candil Orlovsky", while in fruit of control and wide-spread apple cultivars the polyphenolics content is lower: "Severny sinap" - 137 $\mathrm{mg} / 100 \mathrm{~g}$, "Osenneye polosatoye" - $248 \mathrm{mg} / 100 \mathrm{~g}$, "Papirovka" - 259 mg/100 g, "Antonovka obyknovennaya" - 340 mg/100 g (Sedov, Makarkina, Levgerova, 2007).

We have developed apple cultivars with high content of phenolics in fruit (Table 2)

Apple breeding for higher content of ascorbic acid and polyphenolics remains topical, since the introduction of intensive high-vitamin cultivars into production allows increasing dietary and prophylactic value without additional consumption of energy sources.

\section{Breeding for Resistance to Diseases and Pests}

Scab (Venturia inaequalis (Cke. Wint) is one of the most harmful diseases of apple. The decline in the level of apple yield from scab infection in the Middle regions of Russia is not less than $40 \%$ and even 70-80 \%. The All Russian Research Institute of Fruit Crop Breeding is a pioneer in apple breeding for scab immunity with gene $V_{f}$ (Sedov, Zhdanov, 1983; Zhdanov, Sedov, 1991). By nowadays, at our Institute over 30 scab immune apple cultivars have been developed, 20 of them have been already included in the State Register: "Imrus", "Bolotovskoye", "Veniaminovskoye", "Afrodita", "Svezhest", "Orlovskoye polesie", etc.

Brief characteristics of scab immune apple cultivars $\left(V_{f}\right)$ developed at the institute and included in the State Register of Breeding Achievements Admitted for Use are given below (Table 3 ). 
Table 3. Scab immune apple cultivars

\begin{tabular}{|c|c|c|c|c|c|c|}
\hline № & Cultivar name & $\begin{array}{l}\text { Maturing } \\
\text { date }\end{array}$ & Storeability & $\begin{array}{c}\text { Fruit } \\
\text { weight, } \\
\mathrm{g}\end{array}$ & $\begin{array}{c}\text { Fruit } \\
\text { appearance, } \\
\text { point }\end{array}$ & $\begin{array}{c}\text { Fruit taste, } \\
\text { point }\end{array}$ \\
\hline 1 & $\begin{array}{l}\text { Alexandr Boiko (Prima x Tetraploid } \\
\text { Wealthy) }(3 \mathrm{x})\end{array}$ & winter & second decade of March & 200 & 4,4 & 4,3 \\
\hline 2 & $\begin{array}{c}\text { Afrodita } \\
(814-\text { open pollination }) \\
\end{array}$ & $\begin{array}{l}\text { early } \\
\text { winter }\end{array}$ & late December & 130 & 4,4 & 4,4 \\
\hline 3 & $\begin{array}{c}\text { Bolotovskoye } \\
\text { (Skryzhapel x 1924) }\end{array}$ & winter & early February & 150 & 4,3 & 4,3 \\
\hline 4 & $\begin{array}{c}\text { Veniaminovskoye } \\
\text { (814- open polllination) }\end{array}$ & winter & late February & 130 & 4,4 & 4,4 \\
\hline 5 & $\begin{array}{c}\text { Zdorovie } \\
\text { (Antonovka obyknovennaya } \mathrm{x} \\
\text { OR48T47) }\end{array}$ & winter & middle February & 140 & 4,3 & 4,3 \\
\hline 6 & Ivanovskoye (Wealthy x Prima) & winter & middle February & 150 & 4,4 & 4,4 \\
\hline 7 & $\begin{array}{c}\text { Imrus } \\
\text { (Antonovka obyknovennaya. } \mathrm{x} \\
\text { OR18T13) } \\
\end{array}$ & winter & late February & 140 & 4,3 & 4,4 \\
\hline 8 & $\begin{array}{c}\text { Candil orlovski } \\
(1924-\text { open pollination })\end{array}$ & winter & early February & 120 & 4,4 & 4,3 \\
\hline 9 & $\begin{array}{c}\text { Kurnakovskoye } \\
(814 \times \text { PA-29-1-1-63) }\end{array}$ & winter & middle February & 130 & 4,3 & 4,3 \\
\hline 10 & $\begin{array}{c}\text { Maslovskoye } \\
\text { (Redfree x Tetraploid } \\
\text { Papirovka) }(3 \mathrm{x}) \\
\end{array}$ & summer & late September & 220 & 4,3 & 4,3 \\
\hline 11 & $\begin{array}{c}\text { Orlovskoye polesie } \\
(814-\text { open pollination }) \\
\end{array}$ & $\begin{array}{c}\text { early } \\
\text { winter }\end{array}$ & middle January & 140 & 4,4 & 4,3 \\
\hline 12 & $\begin{array}{c}\text { Pamyati Hitrovo } \\
\text { (OR18T13 - open pollination) }\end{array}$ & winter & late February & 170 & 4.3 & 4,3 \\
\hline 13 & $\begin{array}{c}\text { Rozhdestvenskoye } \\
\text { (Wealthy x VM41497)(3x) }\end{array}$ & winter & late January & 140 & 4,4 & 4,3 \\
\hline 14 & $\begin{array}{c}\text { Svezhest (Antonovka krasnobochka } \\
\text { x PR12T67) }\end{array}$ & $\begin{array}{c}\text { late } \\
\text { winter }\end{array}$ & early May & 140 & 4,3 & 4,2 \\
\hline 15 & $\begin{array}{c}\text { Solnyshko } \\
\text { (814-open pollination) }\end{array}$ & $\begin{array}{c}\text { late } \\
\text { autumn }\end{array}$ & early December & 140 & 4,4 & 4,3 \\
\hline 16. & Start (814 x Tetraploid McIntosh) & winter & late February & 140 & 4,3 & 4,3 \\
\hline 17 & $\begin{array}{c}\text { Stroevskoye } \\
(814-\text { open pollination }) \\
\end{array}$ & winter & late February & 120 & 4,5 & 4,4 \\
\hline 18. & $\begin{array}{c}\text { Yubiley Moskvy ( } 814 \text { - open } \\
\text { pollination) }\end{array}$ & winter & late February & 120 & 4,3 & 4,3 \\
\hline 19. & $\begin{array}{c}\text { Yubilar (814 - open pollination) } \\
(3 \mathrm{x})\end{array}$ & summer & late September & 130 & 4,4 & 4,3 \\
\hline 20. & $\begin{array}{c}\text { Yablochny Spas } \\
\text { (Redfree } \mathrm{x} \text { Tetraploid } \\
\text { Papirovka) }(3 \mathrm{x}) \\
\end{array}$ & summer & late September & 210 & 4,4 & 4,3 \\
\hline
\end{tabular}

Note: $\left.{ }^{*}\right)$ Fruit taste and appearance are estimated according to 5-point scale.

Loss of scab resistance by some foreign and home cultivars having gene $V_{f}$ raises a goal of the acceleration and intensification of preventive (forestalling) breeding for disease resistance.

In connection with this, the efforts of breeders must be directed towards the increasing of genetic diversity of cultivars with well-known genes and involving new sources of immunity in breeding; the development of cultivars homozygous according to well-known genes of immunity; the creation of cultivars with two and three genes of immunity; the development of cultivars with a high level of polygenic resistance, and also cultivars having immunity and high field resistance.

In the nearest future, large work on the development of cultivars resistant to wide-spread and harmful powdery mildew and pests (Panonuchus ulmi; Corpocapsa pomonella, etc.) is in prospect. It is necessary to place the breeding work for the development of cultivars with a complex resistance to main diseases and pests on a broad footing.

\section{Development of Triploid Cultivars}


Polyploidy is a genomic mutation, which is displayed in spontaneous or induced increasing of a diploid number of chromosome sets (Zhuchenko, 2004). It has been determined that, as a rule, triploid forms and cultivars are characterized by more regular fruit-bearing, more marketable fruit of larger size, higher autogamy and scab resistance. As far back, as 1930 - 1940, a Swedish scientist Nilsson-Ehle was encouraged with an idea of triploid cultivar breeding by means of crossing diploid cultivars with tetraploid ones (Nilsson-Ehle, 1938, 1944). In 1943 spontaneous tetraploid clones of cultivars "McIntosh", "Ontario", "Papirovka" and "Wealthy" were already known. They were of no interest for use in production because of low quality of fruit, tree vigorousness and lower winter hardiness relative to diploid analogues. Even at that time, the perspective of apple breeding on a polyploidy level was paid much attention. Swedish scientists had a goal to obtain triploid cultivars from crossings of tetraploid cultivars with diploid ones. Those triploid cultivars had to meet economic requirements. It was noted that the development of that trend should consider as an entry into a new era of apple breeding (Einset, 1947; Derman, 1951). However, those works were not properly developed in Sweden.

Iin Russia apple breeding on a polyploidy level was started at the All Russian Research Institute of Fruit Crop Breeding in 1970 (Sedov, Sedysheva, 1985; Sedysheva, Sedov, 1994). The work was carried out jointly with the laboratory of cytoembryology (chief Sedysheva G. A.).

Tetraploid cultivars were used as donors of diploid gametes: "Alfa-68" (4x), tetraploid "McIntosh" (4x), tetraploid "Melba" (4x), tetraploid "Spartan" (4x), and also tetraploid chimaeras: "Antonovka ploskaya" (2-4-4-4x), "Giant Spy" (2-4-4-4x), tetraploid "Papirovka" (2-4-4-4x), tetraploid "Wealthy" (2-4-4-4x) and a number of tetraploid hybrid seedlings (4x).

Fruit shape indices confirm flatter shape of "Antonovka ploskaya" fruit. Fruit of "Tetraploid Wealthy" the same way differ from fruit of the initial diploid form of "Diploid Wealthy" (Sedysheva, Sedov, 1994) (Table 4).

Counting of chloroplast number in guard cells of seedlobe stomas in diploid, triploid and tetraploid apple radicles showed that a number of chloroplasts really increased with ploidy level uplifting. In diploids it was 18, in triploids -22 and in tetraploids -26 , respectively (Solovieva, 1990).

Crossings $4 \mathrm{x} \times 2 \mathrm{x}$ and $2 \mathrm{x} \times 4 \mathrm{x}$ occurred to be the most promising types of crossings for the purpose of triploid seedling obtaining.

As a rule, in triploid seedling fruit there are less seeds than in fruit of diploid seedlings. Thus, in scab immune $\left(\mathrm{V}_{\mathrm{f}}\right)$ diploid seedling 22-39-106 from 814 x Tetraploid Wealthy family there were 13,1 seeds per one fruit, while per one fruit of triploid seedling 22-39-99 from the same family there were only 3,7 seeds, that is 3,5 times less.

In diploid seedling 22-39-45 from 814 x Tetraploid Papirovka family there were 8,7 seeds per one fruit, and in tetraploid seedling 22-38-155 from the same family there were only 3,6 seeds, or 2,4 times less. The same picture in a number of seeds per one fruit in diploid and triploid seedlings was observed in families Antonovka ploskaya open pollination ( 6,0 and 4,2 seeds per one fruit) and Skryzhapel x Antonovka ploskaya ( 8,2 and 5,8 seeds per one fruit). Even greater differences according to a number of normally developed seeds per one fruit were observed in all studied diploid and triploid seedlings. For instance, in diploid scab immune seedling 22-39-33 from $814 \mathrm{x}$ Tetraploid Papirovka family there were 8,3 normally developed seeds per one fruit, on an average, and in triploid seedling 22-39-39 from the same family there was only 1,8 seed.

In diploid seedling 22-39-106 from 814 x Tetraploid Wealthy family there were 10,0 fully developed seeds per one fruit, on an average, and in triploid seedling 22-39-99 from the same family there was 1,6 seed, or 6 times less. A significant difference according to a number of fully developed seeds per one fruit was noted in diploid and triploid seedlings also in other families. In four from six[ cases this difference was confirmed within the third exactness threshold (within 0,999) and in one case - within the first exactness threshold (within 0,95) (Table 5).

Triploid and diploid seedlings differed within one family also in leaf average square, average mass and specific weight. An average leaf square in triploid seedlings in most cases was larger than in diploid seedlings (in 7 cases from 9). In four families the difference in a leaf average square in diploid and triploid seedlings was proved statistically. 
Table 4. Fruit weight and shape in tetraploid sports compared to the initial diploid cultivars

\begin{tabular}{|c|c|c|c|c|}
\hline Cultivar and ploidy level & $\begin{array}{c}\text { Fruit weight, } \\
\mathrm{g}\end{array}$ & $\begin{array}{c}\text { Fruit height, } \\
\mathrm{mm}\end{array}$ & $\begin{array}{c}\text { Fruit width, } \\
\mathrm{mm}\end{array}$ & $\begin{array}{c}\text { Fruit shape index (height } \\
\text { to width ratio) }\end{array}$ \\
\hline Antonovka ploskaya (4x) & 203 & 61 & 76 & 0,80 \\
Antonovka obyknovennaya (2x) & 135 & 58 & 68 & 0,85 \\
\hline LSD $_{0,05}$ & 18 & 2 & 2 & \\
0,01 & 23 & 3 & 78 & 0,77 \\
\hline Wealthy (4x) & 192 & 60 & 67 & 0,82 \\
\hline Wealthy (2x) & 115 & 55 & 3 & \\
\hline
\end{tabular}

Table 5. Seed number per one fruit in apple seedlings of different ploidy (1992).

\begin{tabular}{|c|c|c|c|c|c|}
\hline & \multirow{2}{*}{ Ploidy level and №№ of seedlings } & \multirow{2}{*}{$\begin{array}{l}\text { Seeds in all per one } \\
\text { fruit }\end{array}$} & \multicolumn{2}{|c|}{ Including normally developed seeds } & \multirow{2}{*}{$\begin{array}{l}\text { Per cent differnece in } \\
\text { normally developed } \\
\text { seeds per } 1 \text { fruit }(1-2)\end{array}$} \\
\hline & & & quantity & $\%$ & \\
\hline \multicolumn{6}{|c|}{814 x Tetraploid Papirovka } \\
\hline 1 & $22-39-33(2 x)$ & 9,1 & 8,3 & 91,2 & - \\
\hline 2 & $22-39-39(3 x)$ & 4,5 & 1,8 & 40,0 & $51,2^{* * *}$ \\
\hline 1 & $22-39-45(2 x)$ & 8,7 & 7,7 & 88,5 & - \\
\hline 2 & $22-38-155(3 x)$ & 3,6 & 1,3 & 36,1 & $52,4^{* * *}$ \\
\hline \multicolumn{6}{|c|}{$814 \times$ Tetraploid Wealthy } \\
\hline 1 & $22-39-106(2 x)$ & 13,1 & 10,0 & 76,3 & - \\
\hline 2 & $22-39-99(3 x)$ & 3,7 & 1,6 & 43,2 & $33,1^{* * *}$ \\
\hline \multicolumn{6}{|c|}{ Antonovka ploskaya $(4 x)$ - open pollination } \\
\hline 1 & $18-69-19(2 x)$ & 6,0 & 5,0 & 83,3 & - \\
\hline 2 & $18-69-14(3 x)$ & 4,2 & 1,9 & 45,2 & $38,1^{* * *}$ \\
\hline \multicolumn{6}{|c|}{ Wealthy x Antonovka ploskaya } \\
\hline 1 & $18-66-150(2 x)$ & 5,0 & 3,7 & 74,0 & - \\
\hline 2 & $18-66-46(3 x)$ & 4,9 & 3,3 & 67,3 & $6,7^{*}$ \\
\hline \multicolumn{6}{|c|}{ Skryzhapel x Tetraploid Wealthy } \\
\hline 1 & $18-66-77(2 x)$ & 8,2 & 6,3 & 76,8 & - \\
\hline 2 & $18-66-85(3 x)$ & 5,8 & 4,3 & 74,1 & 2,7 \\
\hline
\end{tabular}

According to our latest data, in the hybridization on a polyploidy level there was obtained 2,3 times less seeds and 4,7 less grown one-year-old seedlings relative to the pollinated flowers than in the hybridization on a diploid level. Nevertheless, the breeding value of seedlings obtained from the hybridization on a polyploidy level was significantly higher. In the hybridization on a polyploidy level for the purpose of selecting an elite seedling it was necessary to grow 4121 seedlings, on an average, and on a polyploidy level -778 seedlings. 86600 flowers were pollinated and 16700 one-year-old seedlings were grown, on an average, for the purpose of one cultivar development on a diploid level, but on a polyploidy level just 46200 flowers were pollinated and 2900 one-year-old seedlings were grown (nearly 6 times less).

In some combinations of crossings on a polyploidy level even less volume of hybridization and hybrid seedling growing was required. Thus, $c v$. "Bezhin lug" was obtained in family Severny sinap $x$ Tetraploid Wealthy from the hybridization in a volume of 13200 flowers and from 709 seedlings. "Avgusta" (Orlik x Tetraploid Papirovka) was obtained from the hybridization in a volume of 8500 flowers and it was released in the family consisting of 912 seedlings.

The problems of study of embryonic structures of the generative sphere of polyploidy forms and the development of express-methods for the identification of polyploids both in the orchard and in the breeding nursery remain to be urgent. These developments will further the intensification of the creation of triploid apple cultivars with a complex of useful characters: disease and pest resistance, regular fruiting and marketable fruit with high taste qualities (Sedov, Sedysheva, Serova, 2008).

High efficiency of apple breeding on a polyploidy level should be noted. It is obvious that apple breeding in this direction has good prospects.

As a rule, triploid cultivars exceed diploid ones in fruit weight.

Among triploid cultivars only $c v$. Nizkorosloye $(130 \mathrm{~g})$ was insignificantly inferior to diploid control cultivars "Antonovka obyknovennaya" (140 g) and "Sinap orlovsky" $(150 \mathrm{~g})$ in fruit weight. Triploid "Patriot" (230 g) was characterized by the largest size of fruit and that cultivar 
significantly exceeded diploid control cultivars.

Study of fruit biochemical composition showed that triploid cultivars were inferior to no diploid control cultivars in the content of sugars. Such cultivars as "Osipovskoye" (12,1 \%), "Spasskoye" (11,9 \%), "Zhilinskoye" (11,4 \%), "Avgusta" (10,5 \%), "Yablchny Spas" (10,4 \%), "Maslovskoye" (10,7 \%) and "Daryona" (10,3 \%) significantly exceeded diploid "Papirovka $(9,0 \%)$.

Triploid cultivars of winter dates of maturing - "Orlovsky partisan" (11,8\%), "Nizkorosloye" $(10,6 \%)$ and "Rozhdestvenskoye" (10,0 \%) substantially exceeded diploid control "Antonovka obyknovennaya $(8,7 \%)$ in the content of sugars. "Orlovsky partisan" $(11,8 \%)$ exceeded another diploid control "Sinap orlovsky" (9,9\%). "Bezhin lug" (9,3\%) and "Pamyt Semakinu" (9,4 \%) did not considerably differ from controls.

The average content of titrated acids in fruit of triploid and diploid control cultivars of summer dates of maturing was actually the same $(0,71 \%$ and $0,73 \%$, respectively). Triploid cultivars "Rodnichok" $(0,87 \%)$, Yubilar $(0,86 \%)$ and Avgusta $(0,73 \%)$ were characterized by higher content of acids in fruit.

Among the cultivars of winter dates of maturing the diploid control cultivar Antonovka obyknovennaya (0,99\%) and triploid cultivar Pamyat Semakinu $(0,77 \%)$ were characterized by high content of titrated acids in fruit. Lower content of titrated acids was noticed in fruit of triploid cultivar "Nizkorosloe" $-0,35 \%$.

Higher content of sugars and not high content of titrated acids in fruit of triploid cultivars of winter dates of maturing ensured higher sugar-acid index $(20,8)$ in comparison with diploid control cultivars $(13,3)$.

We have not revealed any clear constant differences in the content of biologically active substances in fruit of triploid and diploid cultivars. High contents of phenolics in fruit of such triploid cultivars as "Turgenevskoye" $-482 \mathrm{mg} / 100 \mathrm{~g}$, "Pamyat Semakinu" - 501mg/100g and Avgusta $472 \mathrm{mg} / 100 \mathrm{~g}$ and higher content of ascorbic acid in fruit of triploid cultivar "Nizkorosloye" - 18,0mg/100g should be just noted.

New triploid apple cultivars are characterized by higher fruit weight. It has been stated that an average fruit weight of 18 triploid cultivars developed at the institute is $174 \mathrm{~g}$, while an average fruit weight of the best diploid cultivars of the institute breeding is only $136 \mathrm{~g}$. The difference is confirmed statistically. The majority of triploid cultivars do not inferior to diploid wide-spread cultivars in the contents of sugars, phenolics and ascorbic acid and some cultivars significantly exceed them. A number of triploid cultivars exceed diploid ones in taste qualities.

Taking into account more regular fruiting, higher fruit weight and higher content of nutrient and biologically active substances in many triploid cultivars, they are worth of wide testing in production.

By now, 9 cultivars has been developed from crossings $2 x$ $\mathrm{x} 4 \mathrm{x}$ and included in the State Register of Breeding Achievements Admitted for $\mathrm{U}$ se: "Augusta" ('Orlik' $\mathrm{x}$ tetraploid 'Papirovka'), "Aleksandr Boyko" ('Prima x tetraploid 'Wealthy'), "Bezhin lug" ('Severny sinap' $\mathrm{x}$ tetraploid 'Wealthy'), "Dariona" ('Melba' x tetraploid 'Papirovka'), "Maslovskoye" ('Redfree' x tetraploid 'Papirovka'), "Orlovsy partisan" ('Orlik' x 13-6-106), "Osipovskoye" ('Mantet' x tetraploid 'Papirovka'), "Patriot” [16-37-63 ('Antonovka krasnobochka' x SR 0523) x 13-6-106] and "Yablochny Spas" ('Redfree $\mathrm{x}$ tetraploid 'Papirovka'). Cultivars "Aleksandr Boyko", "Maslovskoye" and "Yablochny Spas" have been developed at the All Russian Research Institute of Fruit Crop Breeding (80\%) jointly with the North-Caucuses Research Institute of Horticulture and Viticulture (20\%); the rest cultivars from different-chromosomal crossings have been developed at the All Russian Research Institute of Fruit Crop Breeding. At our Institute 4 cultivars have been created from crossings of two diploid cultivars and included in the State Register: "Nizkorosloye" ('Skryzhapel' x 'Pepin Shafranny'), "Pamyat Semakinu" ('Wealthy x 11-24-28), 'Rozhdestvenskoye" ('Wealthy' x VM41497) and "Yubilar" (814 - open pollination), which have been obtained as a result of occurring of unreduced gametes in one of the parents (Sedov, Sedysheva, 1985; Sedysheva, Sedov, 1994).

The development of triploid scab immune apple cultivars is of exceptional interest. By now, seven such cultivars have been developed, five of which have been obtained from different-chromosomal crossings: "Maslovskoye", "Yablochny Spas", "Spasskoye", "Aleksandr Boyko", "Turgenevskoye" and two cultivars have been obtained from two diploid cultivars - "Rozhdestvenskoye" and "Yubilar".

In prospects, for more efficient work on the development of triploid cultivars it is necessary to form more complete collection of tetraploid forms - donors of diploid gametes for use in breeding, i.e. to reveal and select spontaneous polyploidy seedlings; to obtain polyploids from well-known valuable cultivars (including scab immune ones); with the help of chemicals and methods in vitro it is possible to obtain the unreduced pollen using hit-shocks or colchicine treatments in a meiosis process and with the following use of this pollen for hybridization; to reveal diploid cultivars capable to form the unreduced pollen (Complex programme on pip crop breeding in Russia for 2001-2020. - Orel: VNIISPK, 2001).

\section{Development of Columnar Apple Cultivars for Super Intensive Orchards}

The focused breeding for columnar apples has been carried out at the Institute since 1984. By now, eight cultivars with preliminary names 'Vostorg', 'Girlianda', 'Yesenia', 'Zeliony shum', 'Pamiaty Blynskogo', 'Sozvezdiye', 'Poeziya' and 'Priokskoye' have been created. The latter two cultivars are passing the State Trials. Columnar apple cultivation has a number of advantages. These cultivars give a chance in 3-5 years after orchard planting to obtain a 
significant yield, which cannot be obtained in a traditional orchard. Columnar cultivars developed at our Institute demonstrate sufficient winter hardiness, precocity, productivity, scab resistance and immunity and comparatively high marketable and consumer qualities of fruit (Sedov, Korneyeva, Serova, 2013).

Multi-year investigations have shown the possibility of growing columnar apple cultivars in a crown of winter hardy skeleton of semi-dwarf rootstock 3-4-98 planted with spacing $3 \mathrm{~m} \times 1 \mathrm{~m}$. Such technology of orchard planting allows reducing the demand for planting material by 3-6 times in comparison with the traditional spacing in a columnar orchard, $1 \mathrm{~m} \times 0,4-0,5 \mathrm{~m}$. It also favours the mechanization of protective measures and soil treatments in the orchard.

Columnar cultivars grown in a crown of winter hardy rootstock 3-4-98 are characterized by the greatest economic efficiency when tree planting density is 3333 tree/ha (data of S.A. Korneyeva, 2013). Six year after inoculation (for the first four years of fruit-bearing) all planting expenses were covered and a profit was received.

Columnar orchard cultivation allows reducing the pesticide load in the orchard, it makes labour conditions more comfortable and shows high profitability.

The cultivation of columnar apple cultivars is of special interest for farmers and amateur fruit-growers.

Breeders and agronomists have a goal to improve the columnar apple assortment and the technologies of their cultivation.

\section{Development of Small-Vigorous Intercalary Apple Rootstocks}

Since a set of small-vigorous intercalary rootstocks is limited, it is important to develop new apple forms with various degrees of small vigorousness - from super dwarfish rootstocks to medium vigorous and vigorous ones.

For the purpose of new small-vigorous intercalary rootstock development in 1987 special crossings were made to obtain new forms of rootstocks with different vigour (Sedov, Krasova, Serova et al., 2007). Super dwarf Polish rootstock P-22 was used as a source of dwarfness; highly winter-hardy cultivar "Grushovka moskovskaya" and winter-hardy semi-dwarf rootstocks 3-3-72 and 3-4-98 (S. N. Stepanova's breeding) were taken as the second parent for the crossing. Among hybrid seedlings it was proposed to obtain segregation in vigour from super dwarfs to vigorous forms. 2159 hybrid seedlings were grown from those crossings. In the breeding orchard the culling of rootstock forms was fulfilled. In 1992-1993 budding of 206 selected rootstocks was made on seedlings of wild forest apple; well-known dwarfish rootstocks G-134 and 3-17-38 and semi-dwarf 3-3-72 and 3-4-98 were used as controls. Next year, using those forms as intercalars, cultivars "Bolotovskoye" and "Sinap orlovski" were budded at height
20-22 sm. In 1995-1996 4242 one-year-old nursery-treated plants were planted to the orchard for the further study of growing and fruit-bearing relative to the intercalary stock. Vigour and yield capacity of "Bolotovskoye" and "Sinap orlovskoyi" trees on intercalary stocks were studied during the following years. Rootstocks were subdivided into super dwarfs, dwarfs, semi-dwarfs and vigorous rootstocks. 60 variety-rootstock combinations were selected for the further investigation according to a complex of characters compatibility, vigour, yield capacity and rootstock ability to root. In the nearest future the best hybrid forms will be selected for the purpose of their using as intercalary stocks of different vigour.

\section{True-rooted Culture of Apple}

Apple is traditionally propagated by grafting on a seed or clone rootstock. Propagation on true roots is an alternative propagation way, which excludes grafting.

As far back, as 1940s, the possibility of mass propagation of Michurinsk apple cultivars by horizontal layers was demonstrated (Shub, 1937). It was revealed that true-rooted apples were not inferior to trees grafted on seed rootstocks in general characteristics and productivity (Rauzin, Kharlamova, Dolgikh, 2009). Great work on apple breeding for rooting (root genesis) was carried out at the Mleyevskaya experimental station (Chuprinyuk, 1994, 1995). In the nursery and orchard 2400 seedlings were selected according to the root formation and furrowed knobs (bernots).

The scientists of Timiryazevskaya Agricultural Academy have pointed out the following features of true-rooted culture of apple: 1) more perfect display of cultivar quality characteristics; 2) ability of trees to restore under winter damage at the cost of suckers; 3 ) no need in mother rootstock nursery; 4) possibility to grow trees on the plots with more superficial level of ground water, since a root system in true-rooted plants is more superficial (Maslova, Skaliy, 1985; Isachkin, Kulyamzin, 2011). In opinion of these authors, a number of well-known apple cultivars are able to give a high percent of soft cutting rooting. The advantage of true-rooted apple is displayed in a zone of risky fruit-growing (Maslova, Lunkova, Khadzhiyan, 1997).

At the All Russian Research Institute of Fruit Crop Breeding the work on the development of apple cultivars suitable for true-rooted culture was started in 1984, when five hybrids with well rooting cuttings had been obtained from Mleyevskaya experimental station. In 1989 the hybridization of easily rooting hybrids with scab immune seedlings and winter hardy cultivar "Borovinka" was made.

In another experiment we made an attempt to estimate the ability of scab immune hybrid apple seedlings to give roots in the presence of furrowed knobs (bernots). It is known that the presence of bernots is indicative of rooting degree and possibility of adventitious root appearing (Tzurkan, 1990). In all studied seedlings one of the parents had scab immunity $\left(\mathrm{V}_{\mathrm{f}}\right.$ or $\left.\mathrm{V}_{\mathrm{r}}\right)$. Among seedlings with bernots the best 
ones were selected according to the quality of fruit with average weight $100-140 \mathrm{~g}$, attractiveness $4,0-4,3$ points and taste $3,7-3,9$ points.

The given experimental data and literature references testify to the fact that apple breeding for root genesis is promising and can become an independent section.

\section{Development of Autogamous Apple Cultivars with the Use of Apetalous Apple Forms}

Practically all commercial apple cultivars are auto sterile and for normal fruiting they require planting together with cultivars-pollinators. In conditions of the environmental deterioration in the orchard, denser tree spacing and worse providing with insects-pollinators, the development of autogamous or at least partially autogamous cultivars is especially urgent.

I. P. Yeliseyev (1979) pointed out the perspective of the development of economically valuable apetalous cultivars, which give an opportunity to establish single-varietal orchards. These orchards need neither varieties-pollinators, nor insects providing pollination. Many research workers reported about apetalaous apple trees (Darvin, 1941; Bolotov, 1952; Pashkevich, 1930; S. F. Chernenko, 1953 and others).

Taking into account the significant interest to apetalous apple trees, in 1985 we began to gather apetalous selections for the genetic collection of our Institute. The collection of 13 apetalous apple forms was gathered from various regions of Russia. They had fruit weight from $40 \mathrm{~g}$ to $120 \mathrm{~g}$, fruit appearance 3,5 to 4,2 point and taste $2,0-4,0$ point. Their fruit contained from 0,1 to 5,0 normal well-developed seeds per 1 fruit under open pollination and from 0 to 3,7 seeds under artificial pollination.

In 1990-2004 crossings of apetalous apple forms with scab immune cultivars and hybrid seedlings were made. 2700 one-year-old seedlings were grown, 380 of which were planted in the orchard. Two apetalous seedlings have already been included in the selected ones, since they have qualitative fruit. There is a great practical interest to select candidates into cultivars from hybrid seedlings, which would be apetalous or have normal flowers but could set fruit well without cross pollination.

Undoubtedly, the augmentation of autogamy at the cost of ploidy increase in new cultivars is also of great interest. Our data persuasively point out higher autogamy in triploid cultivars and high autogamy in a number of tetraploid cultivars in comparison with diploid analogues.

\section{Conclusions}

- The long-term study of apple ontogenetic features have allowed the author of this paper accelerating and intensifying the breeding process: 47 apple cultivars have been developed and included in the State Register of Breeding Achievements.

- Regularities of the inheritance of the contents of soluble dry substances, sugars, titrated acids, ascorbic acid and vitamin $\mathrm{P}$ in fruit have been studied.

- 20 scab immune apple cultivars $(V f)$ have been developed and included in the State Register.

- A group of triploid apple cultivars has been obtained from different-chromosomal crossings of the types $2 \mathrm{x} \times 4 \mathrm{x}$ and $4 \mathrm{x} \times 2 \mathrm{x}$, which are characterized by high fruit marketability, more regular yields by years, higher resistance to scab and autogamy.

- 8 columnar apple cultivars for super intensive orchards have been developed, two of them ("Priokskoye" and "Poezia") are passing the state trials now.

- The successful research activity on the development of winter hardy adaptive intercalary stocks has been carried out since 1987.

- A special attention is paid to the prospects of the development of true-rooted culture of apple and creation of autogamy apple cultivars with the use of apetalous apple forms.

Speaking on prospects, it should be noted that global climate changes can lead to the reappraisal of the existing apple assortment and to new goals in breeding.

\section{REFERENCES}

[1] Bolotov, A. T. Illustration and description of different apple and pear races grown at Dvoryaninovo and some other gardens (painted and described by Andrew Bolotov at Dvoryaninovo in 1797-1801) / A. T. Bolotov // Sel. works on agronomy, fruit-growing, forestry, botany. - M.: MOIP, 1952. - P. 241-277.

[2] Darvin, Ch. Changing of animals and plants in domestic condition / Ch. Darvin. - M.: Selkhozgiz, 1941. - 247 p.

[3] Yeliseyev, I. P. Towards origin, polymorphism and evolutional importance of apetalous apple forms / I. P. Eyliseyev // Trudy Gorkovskogo SKhI, 1979.- T.136. S.101-120.

[4] Zhdanov, V. V. Apple breeding for resistance to scab / V. V. Zhdanov, E. N. Sedov. - Tula: Priok. Kn. Izd-vo, 1991. $208 \mathrm{p}$.

[5] Zhuchenko, A. A. Ecological genetics of cultivated plants and problems of agro sphere (theory and practice) A. A. Zhuchenko. - M.: Agrorus, 2004. - T. I. - 690 p.

[6] Isachkin, A. V. Some questions on prospects of apple breeding for rhizogenesis / A. V. Isachkin, E. A. Kulyamzin // Horticulture and viticulture, 2011. - № 3. - P. 23-27.

[7] Kichina, V. V. Principles of orchard plant improvement / V. V. Kichina. - M., 2011. - 528 p. 
[8] Complex programme on pip crop breeding in Russia for 2001-2020 // Resolution of intern. sci. conf. - "Main trends and methods of pip crop breeding". - Orel, 2001.-31 p.

[9] Korneyeva, S. A. Assessment of columnar apples developed at VNIISPK and methods of their cultivation in the intensive orchard / S. A. Korneyeva. - Extended Abstract of Cand. Sci. Dissertation. - Orel, 2013. -22 p.

[10] Maslova, V. A. Growth features of rooted soft cuttings of apple / V. A. Maslova, L. P. Skaliy // Problems of vegetative propagation in horticulture: col. sci. works. - M., 1985. - P. 32-39.

[11] Maslova, V. A. Comparative study of true-rooted apple from soft cuttings and grafted on seedlings of Antonovka obyknovennaya and Paradizka B 9 // V. A. Maslova, V.M. Lunkova, I. I. Khadzhiyan // Izvestiya TSKhA, 1997. Vol.3. - P. 132-147.

[12] Methods of plant biochemical investigation / [A. I. Yermakov, V. V. Arasimovich, N. P. Yarosh, et al.]. L.: Agropromizdat, 1987. - 430 p.

[13] Pashkevich, V. V. General pomology or scientists about fruit varieties / V. V. Pashkevich. - L.; M.: Gosizdat, 1930. - P. 29.

[14] Programme and methods of breeding of fruit, berry and nut crops / edited by G. A. Lobanov. - Michurinsk, 1980. - 407 p.

[15] Programme and methods of breeding of fruit, berry and nut crops / edited by E. N. Sedov. - Orel: VNIISPK, 1995. - 504 p.

[16] Rauzin, E. G. True-rooted culture of fruit plants / E. G. Rauzin, T. A. Harlamova, S. G. Dolgikh // Works of Kazakhsky Res. Inst. of Fruit-Growing and Viticulture. 2009. - P. 7-10

[17] Sedov, E. N. Breeding of small-vigorous intercalary clone apple stocks at the VNIISPK / E.N. Sedov, N. G. Krasova, Z. M. Serova, N. M. Glazova, A. A. Bologov // Breeding and variety propagation of orchard crops. - Orel: VNIISPK, 2007. - P. 162-170.

[18] Sedov E. N. Biochemical and technological characteristics of fruit of apple gene pool/ E/ N/ Sedov, M. A. Makarkina, N. S. Levgerova. - Orel: VNIISPK, 2007. - 310 p.

[19] Sedov E. N. Columnar apple in the intensive orchard / E. N. Sedov, S. A. Korneyeva, Z. M. Serova. - Orel: VNIISPK, 2013. -64 p.

[20] Sedov, E. N. Polyploidy role in apple breeding/ E. N. Sedov, G. A. Sedysheva. - Tula: Priok. Kn. Izd-vo, 1985. - 146 p.
[21] Sedov, E. N. Breeding and new cultivars of apple. - Orel: VNIISPK. $-624 \mathrm{p}$.

[22] Sedov, E. N. Apple breeding in connection with some questions of ontogenesis / E. N. Sedov // Breeding and variety investigation of fruit and berry crops in the Nechernozem zone. - M.; Kolos, 1966. - P. 59-70.

[23] Sedov, E. N. Development of valuable donors of diploid gametes for apple breeding on a polyploidy level / E. N. Sedov, G. A. Sedysheva, Z. M. Serova // Vestnik Rosselkhozakademii. - 2011. - № 3. - P. 37-39.

[24] Sedov E. N. Apple resistance to scab (varieties and breeding) / E. N. Sedov, V. V. Zhdanov - Orel: Priok. Kn. Izd-vo, 1983. $-116 \mathrm{p}$.

[25] Edov, E. N. Juvenile period and apple and pear breeding / E. N. Sedov // Breeding, variety investigation and agronomical practices of fruit and berry crops. - Orel: Priok. Kn. Izd-vo, 1968. - V. 2. - P. 3-60.

[26] Sedysheva, G. A. Polyploidy in apple breeding / G. A. Sedysheva, E. N. Sedov. - Orel: VNIISPK, 1994. - 272 p.

[27] Tzurkan, I. P. Bernots // Horticulture. Encyclopaedia. Kishinev: Gl. Red. Mold. sov. enc., 1990. - T.1. - P. 134.

[28] Chernenko, S. F. Apetalous apple / S. F. Chernenko // Nature, 1953. - №12. P. 105-108.

[29] Chuprinuk, V. Ya. Root genesis in domestic apple breeding / V.Ya Chuprinuk // Planting material for intensive orchards. - Warsaw, 1994. - P. 71-72.

[30] Chuprinuk, V. Ya. Apple breeding for root genesis / V.Ya Chuprinuk // Followers of L. P. Simirenko - to horticulture of the Ukraine: col. sci. works to 140-year of L.P. Simirenko. - Cherkasy, 1995. - S. 22-31.

[31] Shub, D. B. Growing of true-rooted trees of Michurinsk cultivars // Fruit-and-vegetative farming. - 1937. - №6. P.32-36.

[32] Dermen, H. Tetraploid and diploid adventitious shoots from a giant sport of McIntosh apple // J. Hered., 1951. - 42. - P. 144-149.

[33] Einset, J. Apple breeding enters a new era // Fm Res., N.Y., 1947. - 13(2). - P.5.

[34] Nilsson-Ehle, H. Production of tetraploid apples and their significance for practical apple breeding in Sweden // Hereditas, Lund, 1938. - 24. - P. 195-209.

[35] Nilsson-Ehle, H. Some new information about tetraploid apple varieties and their use and role in the breeding of fruit trees // Sverig. Pomol. Fören Årsskr., 1994. - P. 229-237. 